\title{
Developing GIS-Based Unit Hydrographs for Flood Management in Makkah Metropolitan Area, Saudi Arabia
}

\author{
Gomaa M. Dawod $^{1,2}$, Nabeel A. Koshak ${ }^{3}$ \\ ${ }^{1}$ Survey Research Institute, Giza, Egypt \\ ${ }^{2}$ Umm Al-Qura University, Makkah, Saudi Arabia \\ ${ }^{3}$ Center of Research Excellence in Hajj and Omrah, Umm Al-Qura University, Makkah, Saudi Arabia \\ E-mail:dawod_gomaa@yahoo.com,nakoshak@uqu.edu.sa \\ Received March 6, 2011; revised March 31, 2011; accepted April 2, 2011
}

\begin{abstract}
Unit hydrographs (UH) are either determined from gauged data or derived using empirically-based synthetic unit hydrograph procedures. In Saudi Arabia, the discharge records may not be available either for several locations or for long time scales, and therefore synthetic unit hydrographs are crucial in flood and water resources management. Available metrological, geological, and land use datasets have been utilized in order to apply the US National Resources Conservative Services (NRCS) methodology in a Geographic Information Systems (GIS) environment. Furthermore, NRCS unit hydrographs have been developed for six watersheds within Makkah metropolitan area, southwest Saudi Arabia. The accomplished results show that the UH time to peak discharge vary from 1.15 hours to 4.47 hours, and the UH peak discharge quantities range from $10.14 \mathrm{~m}^{3} / \mathrm{s}$ to $16.74 \mathrm{~m}^{3} / \mathrm{s}$. It is concluded that the third basin in Makkah city may be considered as the most hazardous catchment. Hence, it is recommended that careful flood protection procedures should be taken in this area within Makkah city.
\end{abstract}

Keywords: GIS, Unit Hydrograph, NRCS, Flood Management, Saudi Arabia

\section{Introduction}

Flood modeling usually involves approximate descriptions of the rainfall-runoff transformation processes, based on empirical, or physically-based, or combined descriptions of the physical processes involved. The resulting models are quite useful in practice since they are simple and provide adequate estimates of flood hydrographs. Sherman [1] first proposed the unit hydrograph (UH) concept. The UH of a watershed is defined as the direct runoff hydrograph resulting from a unit volume of excess rainfall of constant intensity and uniformly distributed over the drainage area. The UH approach is applied for several engineering designs and environmental studies [2,3] Detailed descriptions of UH types and formulas can be found in several literatures [4,5]. Moreover, the Geographic Information Systems (GIS) technology has been applied for flood management based on utilizing unit hydrographs [6-8].

\section{Objectives}

The current research study aims to:
- Utilize the unite hydrograph approach for flood characterizing in Makkah city, Saudi Arabia.

- Compute the requited quantities of unit hydrographs for six hydrological basins within the study area.

- Apply the US National Resources Conservative Service (NRCS) methodology to develop unit hydrographs, for the first time in Saudi Arabia.

- Perform flood assessment computations within a GIS environment as a precise, effective, and fast technological tool.

\section{Previous Works}

Sets of observations of effective rainfall and direct runoff are required for the derivation of unit hydrographs. When no direct observations are available, or when UH's for other locations on the stream in the same watershed or for nearby watersheds of similar characteristics are required, Synthetic, or conceptual, Unit Hydrograph (SUH) procedures must be used [9]. SUH procedures can be categorized as [10]: 1) those based on models of watershed storage; 2) those relating hydrograph characteristics 
to watershed characteristics [11]; and 3) those based on a dimensionless unit hydrograph [12,13].

In Kingdom of Saudi Arabia (KSA) the Snyder UH is the most common method in a variety of geomorphologic and flood literatures [14,15]. However, a crucial issue in this model is the existence of two parameters (namely: $C_{t}$ a coefficient represents variations in watershed slopes and storage characteristics; and $C_{p}$ a coefficient represents the effects of retention and storage) that need to be determined from actual observations for the specific watershed or can be taken from some other watersheds that have similar topographic and morphometric characteristics. Hence, empirical approach is suggested as an alternative for constructing a dimensionless UH for ungauged basins in southwest region of KSA [16,17]. The Soil Conservative Service (SCS) method is seldom utilized, particularly in few academic studies in KSA [18].

\section{Materials and Methods}

\subsection{NRCS Hydrographs’ Method}

The National Resources Conservative Service (NRCS), formally SCS, UH approach represents an optimum dimensionless UH method, that are extensively utilized in the last few years in several countries [19-22]. The NRCS dimensionless UH was developed based on an extensive analysis of measured data for a large number of actual watersheds and then made dimensionless by dividing all discharge ordinates by the peak discharge and the time ordinates by the time to peak. The time base of the dimensionless UH was approximately 5 times the time to peak, and approximately $3 / 8$ of the total volume occurred before the time to peak; the inflection point on the recession limb occurs at approximately 1.7 times the time to peak, and the UH has a curvilinear shape [23]. The discharge ratios for selected values of the time ratios are given in Table 1.

The mathematical formulas of the requited parameters, to construct the NRCS UH for watersheds, are:

$$
q p=q u A Q
$$

where,

$q p=$ peak discharge $\left(\mathrm{m}^{3} / \mathrm{s}\right)$
$A=$ drainage area $\left(\mathrm{km}^{2}\right)$
$Q=$ depth of runoff $(\mathrm{mm})$
$q u=$ unit peak discharge $\left(\mathrm{m}^{3} / \mathrm{s} / \mathrm{km}^{2} / \mathrm{mm}\right)$ that can be

$q u=$ unit peak discharge $\left(\mathrm{m}^{3} / \mathrm{s} / \mathrm{km}^{2} / \mathrm{mm}\right)$ that can be computed from corresponding tables [23, pp. 5-28].

The time of concentration, tc, is the time needed for a drop of water to move from the most distant point in the watershed to the design point downstream (taken as the basin outlet in the current study). There are numerous
Table 1. Some ratios for NRCS dimensionless UH.

\begin{tabular}{cccc}
\hline $\begin{array}{c}\text { Time Ratio } \\
\mathrm{t} / \mathrm{T}_{\mathrm{p}}\end{array}$ & $\begin{array}{c}\text { Discharge Ratio } \\
\mathrm{q} / \mathrm{q}_{\mathrm{p}}\end{array}$ & $\begin{array}{c}\text { Time Ratio } \\
\mathrm{t} / \mathrm{T}_{\mathrm{p}}\end{array}$ & $\begin{array}{c}\text { Discharge Ratio } \\
\mathrm{q} / \mathrm{q}_{\mathrm{p}}\end{array}$ \\
\hline 0 & 0.000 & 0.9 & 0.990 \\
0.1 & 0.030 & 1.0 & 1.000 \\
0.2 & 0.100 & 1.5 & 0.680 \\
0.3 & 0.190 & 2.0 & 0.280 \\
0.4 & 0.310 & 3.0 & 0.055 \\
0.5 & 0.470 & 3.6 & 0.021 \\
0.6 & 0.660 & 4.0 & 0.011 \\
0.7 & 0.820 & 4.5 & 0.005 \\
0.8 & 0.930 & 5.0 & 0.000 \\
\hline
\end{tabular}

After [23, p. 6-59].

empirical equations to calculate tc, such as: Jaton formula [24], kirpich formula [25], and kirpich/Ramser formula [8]. However, the NRCS formula for time of concentration [18] is given by [26, pp. 3-9]:

$$
\text { tc }=1.67\left[L^{0.8}(S+1)^{0.7}\right] /\left[1900 * S L^{0.5}\right]
$$

where,

tc $=$ concentration time (minutes),

$L=$ length of basin main stream (feet)

$S L=$ average watershed land slope in percentage.

$$
Q=(P-0.2 S)^{2} /(P+0.8 S)
$$

where,

$Q=$ depth of direct runoff (mm)

$P=$ depth of precipitation for a specific return period (mm)

$S=$ maximum potential retention $(\mathrm{mm})$ :

$$
S=25.4((1000 / \mathrm{CN})-10)
$$

where $\mathrm{CN}$ is the curve number, a coefficient determined based on geological, soil, and land use properties for each basin.

\subsection{Materials}

Makkah city is located in the south-west part of KSA, about $80 \mathrm{Km}$ east of the Red Sea (Figure 1). It extends from $39^{\circ} 35^{\prime} \mathrm{E}$ to $40^{\circ} 02^{\prime} \mathrm{E}$, and from $21^{\circ} 09^{\prime} \mathrm{N}$ to $21^{\circ} 37^{\prime} \mathrm{N}$. The area of the metropolitan region (the study area) equals 1593 square kilometers approximately. The topography of Makkah is complex in nature, and several mountainous areas exist inside its metropolitan area. The winter is considered as the main rainy season in Saudi Arabia. The annual rain over Makkah city, for a period 


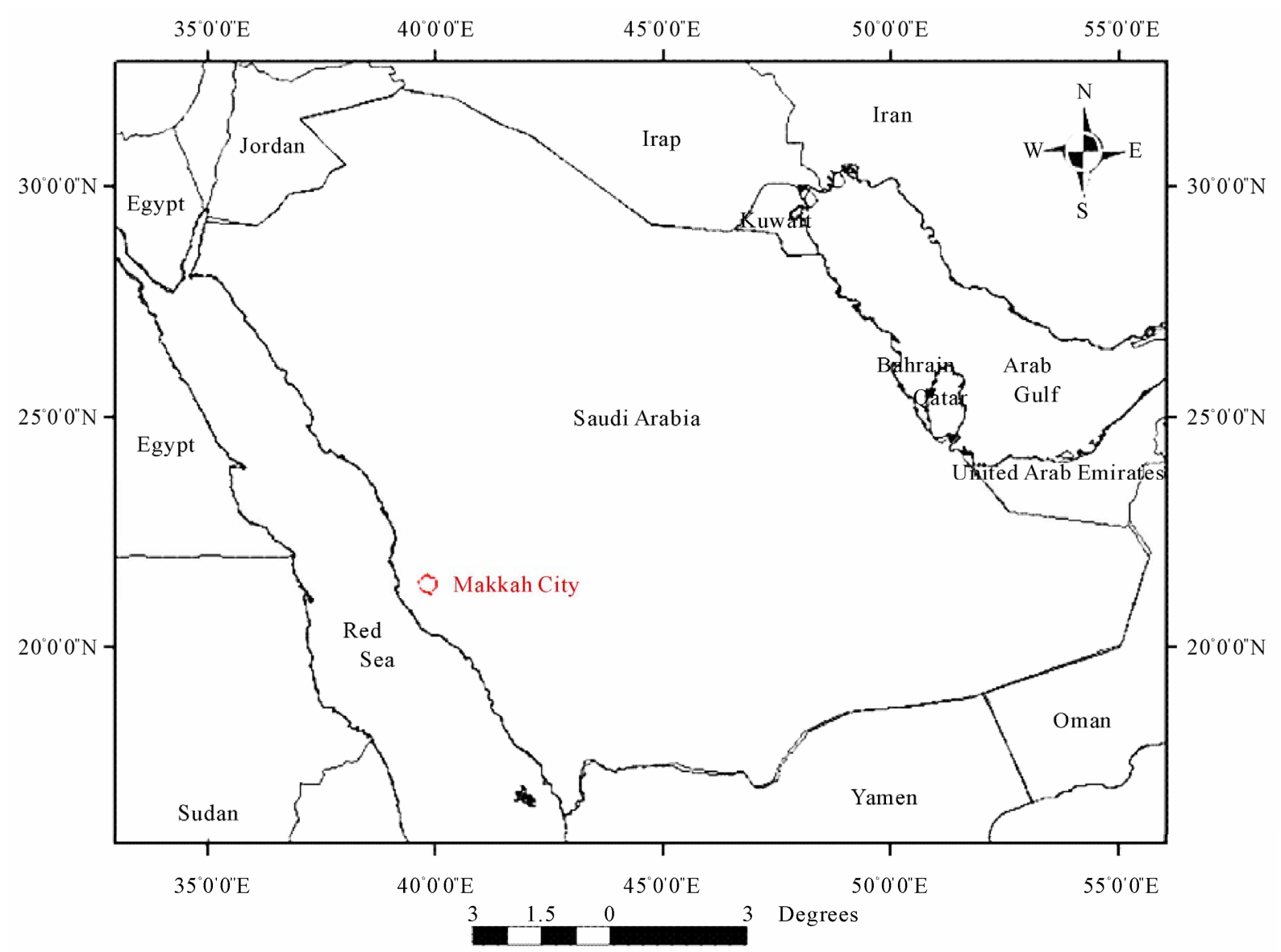

Figure 1. Study area.

extends from 1966 to 2009, varies from $3.8 \mathrm{~mm}$ to 318.5 $\mathrm{mm}$, with an average of rainfall equals $101.2 \mathrm{~mm}$. Due to the complexity of Makkah's topography, flash floods occurs periodically with significant variations in magnitude [27]. The rain intensity in a single extreme storm may exceed the annual rain average in that year.

Several datasets have been collected for the cause of flood assessment. The main data set, of the current study, is a Digital Elevation Model (DEM) for the study area. The acquired DEM produced by the by King Abdulaziz City of Sciences and Technology (KACST) with a spatial resolution equals 5 meters. A window covers Makkah metropolitan area has been provided through the Center of Excellence in Hajj and Omrah, Umm Al-Qura university. Mirza et al. [28] confirm that that national DEM is 3 times more accurate than published global DEMs (ASTER and SRTM 3). The other collected datasets include digital geological, soil, and land uses maps of the study area. The Arc GIS v.10 software has been utilized, in the current study, to delineates the main catchments in Makkah based on the available DEM. Six main basins are identified those area ranged from 74.3 to 360.6 square kilometers, and lengths of their main streams vary from 16.50 to 48.55 kilometers (Figure 2). Table 2 presents statistics of some accomplished hydrological parameters of these catchments.

\section{Results}

Dawod et al. [29] computed CN, runoff depth, peak discharge, and time of concentration for the six basins in Makkah metropolitan area. In that study, a GIS-based methodology has been developed for quantifying and spatially mapping the flood characteristics. The core of that approach is integrating several topographic, metrological, geological, and land use datasets in a GIS environment that utilizes the NRCS method of flood modelling for ungauged arid catchments. The computations have performed using the depth of precipitation (P) equals $200 \mathrm{~mm}$ for a return period of 50 years. Additionally, the calculations of flood quantities, such as depth and volume of runoff (Equations 3 and 4), were performed in the attribute tables of GIS layers, in order to assemble all results in the same environment. Table 3 presents these quantities.

The NRCS UH methodology, as described above, has 


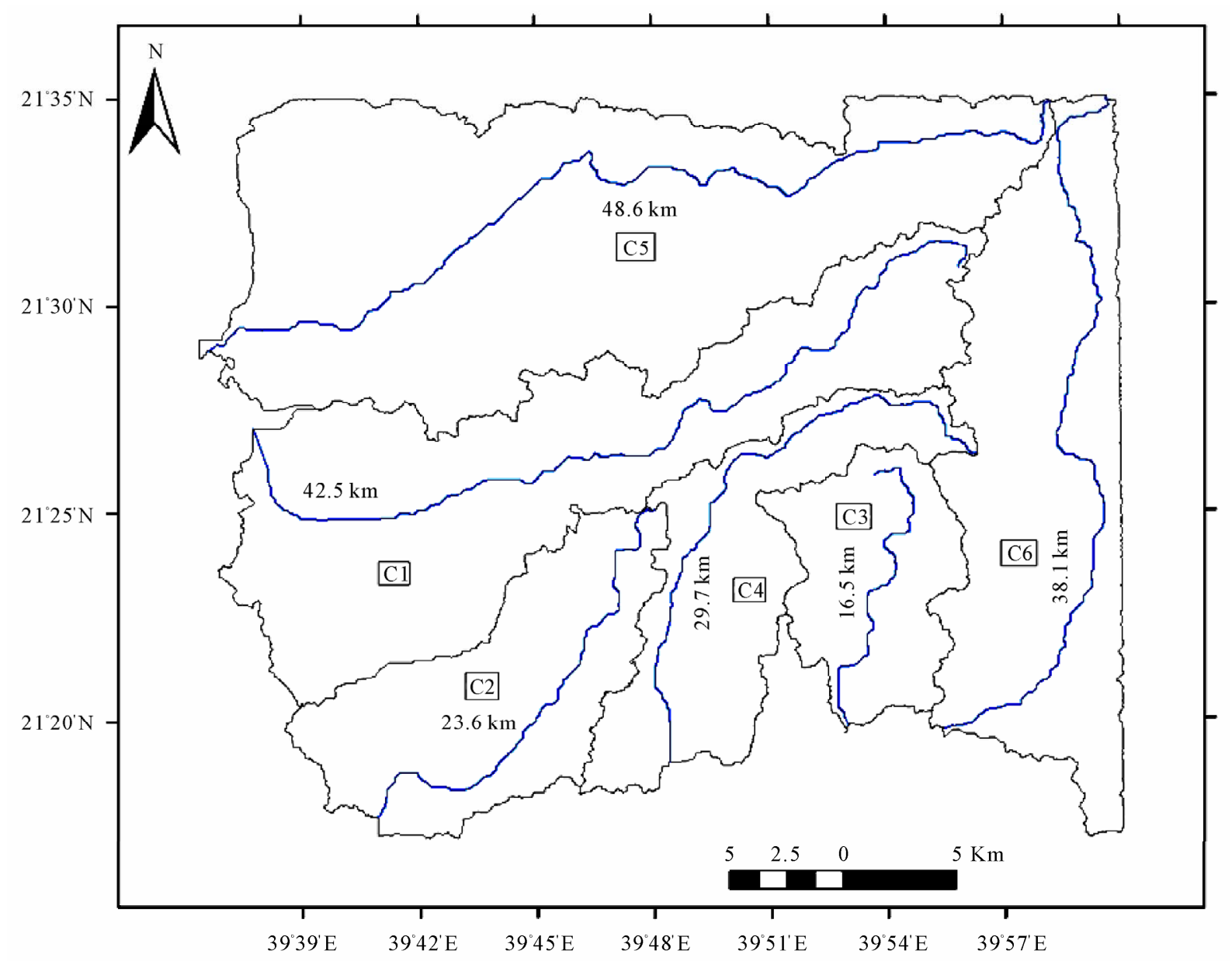

Figure 2. Catchments and their main streams in Makkah.

Table 2. Statistics of morphometric quantities.

\begin{tabular}{ccccccc}
\hline Item & C1 & C2 & C3 & C4 & C5 & C6 \\
\hline Basin Area $\left(\mathrm{km}^{2}\right)$ & 252.7 & 122.3 & 74.3 & 109.9 & 360.6 & 200.2 \\
Basin Premier $(\mathrm{km})$ & 134.6 & 69.13 & 50.23 & 89.09 & 134.76 & 102.03 \\
Length of Main Stream $(\mathrm{km})$ & 42.48 & 23.64 & 16.50 & 29.70 & 48.55 & 38.13 \\
\hline
\end{tabular}

Table 3. NRCS-based hydrological results in the study area.

\begin{tabular}{cccccccc}
\hline Item & C1 & C2 & C3 & C4 & C5 & C6 \\
\hline CN & 84 & 84 & 93 & 89 & 84 & 83 \\
Time of concentration (hours) & 5.69 & 3.76 & 1.73 & 2.63 & 6.72 & 4.17 \\
Runoff depth (mm) & 152 & 152 & 179 & 167 & 152 & 149 \\
Peak discharge (m3/s) & 1554 & 1063 & 1307 & 1234 & 4489 & 1514 \\
\hline
\end{tabular}

been applied, for the first time in Saudi Arabia, for the six watersheds of Makkah metropolitan area. The accomplished results are presented in Table $\mathbf{4}$ and depicted in Figure 3. It can be seen that the elapsed time from rainfall start to peak discharge vary from 1.15 hours (in catchment C3) to 4.47 hours (for catchment 6). Secondly, it has been found that the UH peak discharge quantities range from $10.14 \mathrm{~m}^{3} / \mathrm{s}$ (for catchment 2) to $16.74 \mathrm{~m}^{3} / \mathrm{s}$ 


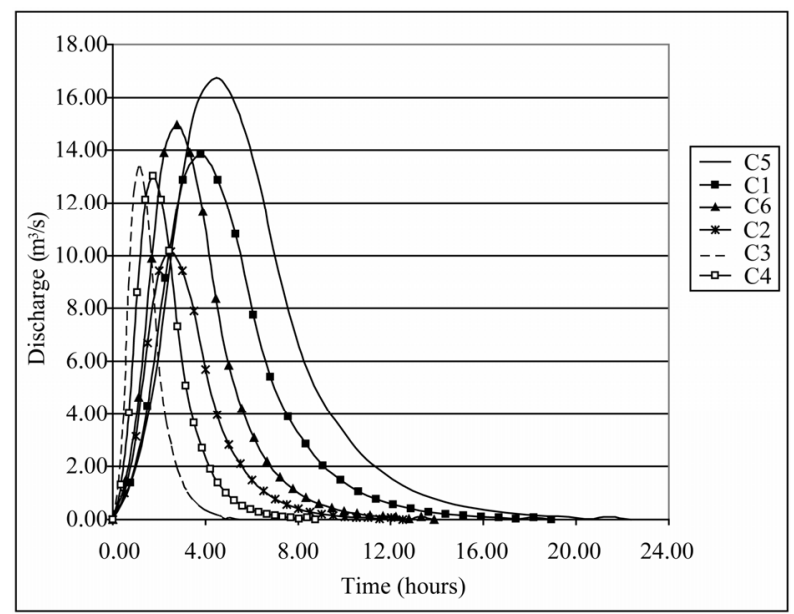

Figure 3. NRCS Unit Hydrographs of Makkah’ Catchments. (for catchment 5). Furthermore, the total runoff time varies from 5.75 hours (for catchment 3) to 22.34 hours (for catchment 5). The same results can be visualized graphically from Figure 3.

Moreover, a correlation analysis has been performed between the main morphometric and NRCS UH parameters of the six basins. The results (Table 5) showed that the basin area, with a positive correlation equaling to 0.74 , is the most effective element that influences the UH peak discharges. In addition, the time of concentration also resulted in moderate positive correlation values, 0.55 .

\section{Discussion}

Results in Table 4 indicate that the smallest elapsed time is 1.15 hours (in catchment C3). Recall from Table 3,

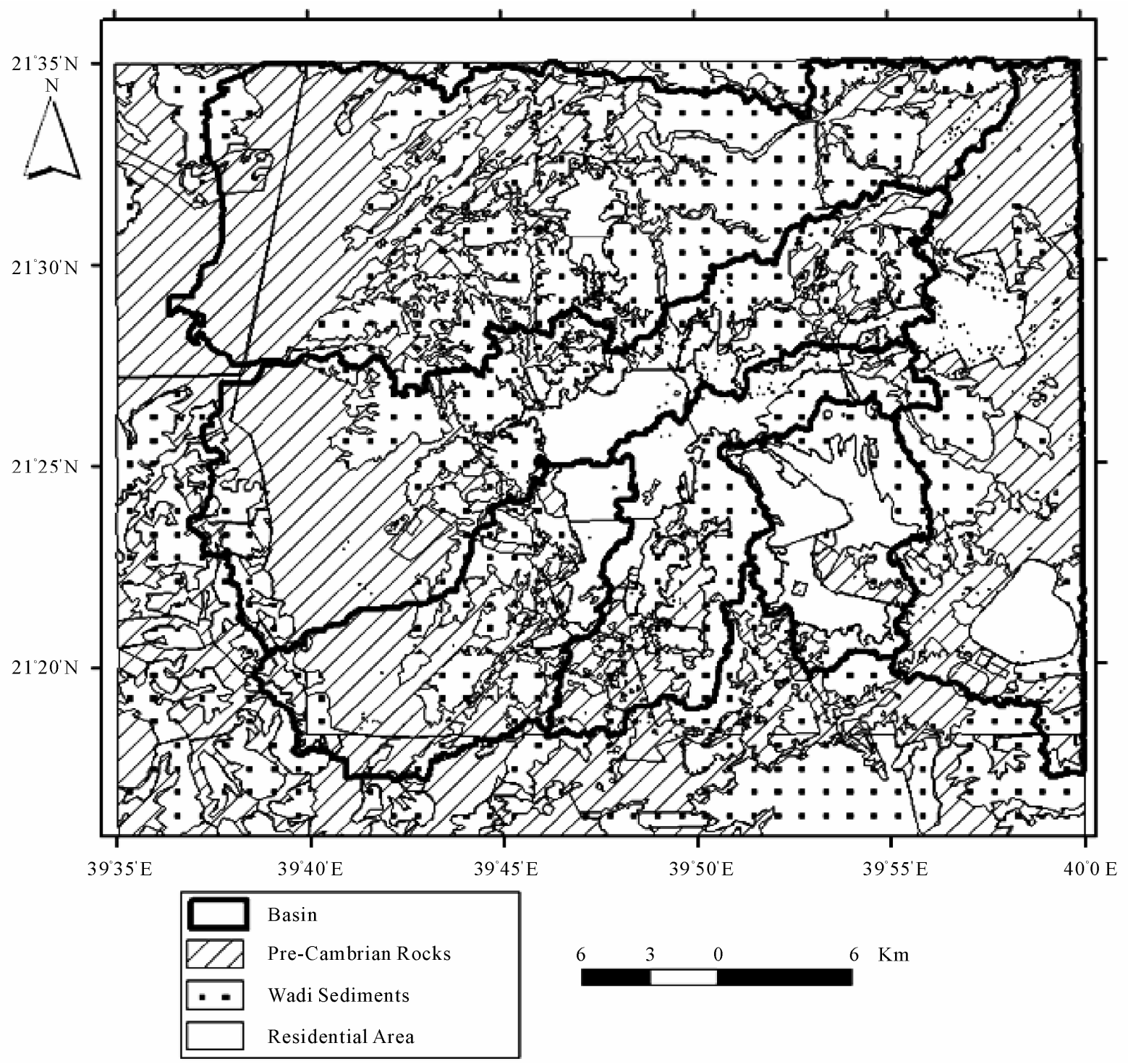

Figure 4. Geology and land use of Makkah' catchments. 
Table 4. NRCS UH quantities for Makkah' catchments.

\begin{tabular}{ccccccc}
\hline Item & C1 & C2 & C3 & C4 & C5 & C6 \\
\hline Time to Peak (hours) & 3.78 & 2.50 & 1.15 & 1.75 & 4.47 & 2.78 \\
UH Peak discharge $\left(\mathrm{m}^{3} / \mathrm{s}\right)$ & 13.86 & 10.14 & 13.40 & 13.04 & 16.74 & 14.96 \\
Total Time (hours) & 18.92 & 12.51 & 5.75 & 8.74 & 22.34 & 13.88 \\
\hline
\end{tabular}

Table 5. Correlation between main morphometric and UH parameters.

\begin{tabular}{cccc}
\hline Item & $\begin{array}{c}\text { UH Peak } \\
\text { Discharge }\end{array}$ & $\begin{array}{c}\text { Basin } \\
\text { area }\end{array}$ & $\begin{array}{c}\text { Time of } \\
\text { concentration }\end{array}$ \\
\hline UH Peak Discharge & 1 & & \\
Basin area & 0.74 & 1 & \\
$\begin{array}{c}\text { Time of } \\
\text { concentration }\end{array}$ & 0.55 & 0.97 & 1 \\
\hline
\end{tabular}

this catchment has the higher $\mathrm{CN}$ value, since it mainly constitutes of residential areas (Figure 4) which have the least permeability property. Hence, it can be concluded that the third basin in Makkah city may be considered as the most hazardous catchment. Also, the total runoff time for this basin reaches 5.75 hours, which is another evident that the third basin in Makkah city may be considered as the most hazardous catchment. The same conclusions can be drawn from the inspection of Figure 3, where the $\mathrm{UH}$ of this particular basin has the least time-to-peak and total runoff time. That leads to the fact that there is no enough time, in case of floods, for both the residents and the governmental authorities to evacuate people or apply precaution procedures. Hence, careful flood protection policies should be taken in this area within Makkah city. Moreover, it has been found that the maximum UH peak discharge equals $16.74 \mathrm{~m}^{3} / \mathrm{s}$ (for catchment 5). Although this catchment produces the highest peak discharge, its time to peak is relatively large (4.47 hours), which might gives suitable enough time for residents to get ready and receive some governmental assistance.

\section{Conclusions}

Unit hydrographs graphically represent the direct runoff resulted from a unit volume of excess rainfall of constant intensity and uniformly distributed over the drainage area. Out of several methods of unit hydrographs developments, the NRCS represent an optimum approach for ungauged watersheds, since it incorporates several data types of the area of interest. The current research study has utilized a high-resolution DEM in order to apply the NRCS approach for flood assessment. NRCS- based unit hydrographs have been developed for basins within
Makkah metropolitan area, southwest of Saudi Arabia. The attained results show that the time to peak discharge vary from 1.15 hours to 4.47 hours, and the UH peak discharge quantities range from $10.14 \mathrm{~m}^{3} / \mathrm{s}$ to $16.74 \mathrm{~m}^{3} / \mathrm{s}$. It is concluded that the third basin in Makkah city may be considered as the most hazardous catchment, since it has the least UH time-to-peak and total runoff time. Hence, it is recommended that careful flood protection procedures should be taken in this area within Makkah city.

\section{Acknowledgements}

The authors would like to acknowledge the financial support offered by the Center of Research Excellence in Hajj and Omrah, Um Al-Qura university, Saudi Arabia.

\section{References}

[1] L. Sherman, "Stream Flow from Rainfall by the Unit Graph Method,” Engineering News Record, No. 108, 1932, pp. 501-505.

[2] D. Roy and D. Banerjee, "Performance Analysis of the Proposed Reservoir Project in the State of West Bengal," Hydrology and Earth System Sciences Discussions, Vol. 7, No. 1, 2010, pp. 1373-1405. doi:10.5194/hessd-7-1373-2010

[3] T. Reshma, P. Kumar, M. Babu and K. Kumar, "Simulation of Runoff in Watersheds Using SCS-CN and Muskingum-Cunge Methods Using Remote Sensing and Geographical Information Systems," International Journal of Advanced Science and Technology, Vol. 25, 2010, pp. 31-42.

[4] T. Davie, "Fundamentals of Hydrology," 2nd Edition, Rout- ledge Inc., New York, 2008.

[5] H. Raghunath, "Hydrology: Principles, Analysis, and Design,” 2nd Edition, New Age International Limited, New Delhi, 2006.

[6] S. Al-Jabari, M. Abu Sharakh and Z. Al-Mimi, "Estimation of Runoff for Agricultural Watershed Using SCS Curve Number And GIS,” Proceedings of the thirteenth International Water Technology Conference, Hurghada, 2009, pp. 1213-1229.

[7] J. Lee, J. Yang and J. Choi, "Development of Integrated GIS Interface For Characteristics of Regional Daily Flow," World Academy of Science, Journal of Engineering and Technology, Vol. 28, 2007, pp. 180-185. 
[8] Y. Sherief, "Flash Floods and Their Effects on the Development in El-Qaá Plain Area in South Sinai, Egypt, a Study in Applied Geomorphology Using GIS and Remote Sensing,” PhD Dissertation, Mainz University, Germany, 2008.

[9] J. Wilkerson, "Regional Regression Equations to Estimate Synthetic Unit Hydrograph Parameters for Indiana,” MSC thesis, Purdue University, USA, 2009.

[10] J. Ramírez, "Prediction and Modeling of Flood Hydrology and Hydraulics," In: E. Wohl, Ed., Inland Flood Hazards: Human, Riparian and Aquatic Communities, Cambridge university press, New York, 2000.

[11] F. F. Snyder, "Synthetic Unit Graphs," Transactions American Geophysics Union, Vol. 19, 1938, pp. 447-454.

[12] SCS (US Soil Conservation Service), "Sec. 4 of National Engineering Handbook," Soil Conservation Service, U.S. Department of Agriculture, Washington, D.C., 1972.

[13] NRCS (US National Resources Conservation Services), "Urban Hydrology for Small Watersheds," Technical Manual TR55, 1986.

[14] F. Al-Juaidi, "Hydro-Morphometric and Flow Characteristics of the Suggested Dams Basins in Ulaya wadis, AlKharj (in Arabic)," Research Papers in Geography, Vol. 84, Riyadh, 2008.

[15] H. Al-Ghilan, "The Role of GIS in Sustainable Development (In Arabic)," Proceedings of the Fifth Arab Geographers, Kuwait, 5-7 April 2009, pp. 1332-1413.

[16] Z. Sen, "Modified Hydrograph Method for Arid Regions,” Journal of Hydrological Processes, Vol. 22, 2008, pp. 356-365. doi:10.1002/hyp.6601

[17] S. Sirdas and Z. Sen, "Determination of Flash Floods in Western Arabian Peninsula," ASCE Journal of Hydrologic Engineering, Vol. 12, No. 6, 2007, pp. 676-581. doi:10.1061/(ASCE)1084-0699(2007)12:6(676)

[18] H. Al-Nofai, "Estimating Runoff and Flood Hazards in the Upper Basin of Oranah Valley, East Makkah, through Remote Sensing and Geographic Information Systems (In Arabic),” MSC Thesis, Umm Al-Qura University, Makkah, 2010.

[19] W. Adebayo, O. Solomon, M. Ayanniyi and F. Sikiru, "Evaluation of Synthetic Unit Hydrograph Methods for the Development of Design Storm Hydrographs for Rivers in South-West, Nigeria,” Journal of American Science,
Vol. 5, No.4, 2009, pp. 23-32.

[20] G. Gul, N. Harmancioglu and A. Gul, “A Combined Hydrologic and Hydraulic Modeling Approach for Testing Efficiency of Structural Flood Control Measures,” Journal of Natural Hazards, 2009.

[21] A. Bradley, L. Wehmeyer and L. Chen, "Evaluation of Design Flood Frequency Methods for Iowa Streams," Report No. TR-533, Iowa Department of Transportation, Iowa State, 2009.

[22] A. Salami, "Evaluation of Methods of Storm Hydrograph Development,” International Egyptian Engineering Mathematical Society (IEEMS), Vol. 6, 2009, pp. 17-28.

[23] US DoT (US Department of Transportation), "Highway Hydrology,” 2nd Ed., U.S. Department of Transportation Federal Highway Administration, 2002.

[24] M. Mirza and M. Barodi, "Geological Basis and Their Role in Surface Feature Development in Haram Area, Makkah,” Social Science Researches, Vol. 56, 2004.

[25] E. Daniil and S. Michas, "Use of Digital Elevation Models for the Determination of Storm Water Discharges for Highway and Railway Projects," Proceedings of the 33rd Congress of the International Association of Hydraulic Engineering and Research, Vancouver, 9-14 August 2009, pp. 2771-2778.

[26] MHP (Maryland Hydrology Panel), “Applications of Hydrologic Methods in Maryland,” Technical Manual, 2nd Editon, Maryland Hydrology Panel, Maryland State, 2005.

[27] A. Shehata and N. Koshak, "Using 3D GIS to Assess Environmental Hazards in Built Environments, Case Study: Mina,” Al-Azhar Engineering Journal, Vol. 2, No. 2, 2007, pp. 1-13.

[28] M. Mirza, G. Dawod and K. Al-Ghamdi, “Assessment of Global and National Digital Elevation Models for Geodetic and Geomorphologic Applications in Makkah Metropolitan Area, Saudi Arabia," XXV IUGG General Assembly, Melbourne, 28 June - 7 July 2011.

[29] G. Dawod, M. Mirza and K. Al-Ghamdi, “A GIS-Based Approach for Estimating Flash Flood Hazards in Makkah Metropolitan Area, Saudi Arabia,” International Journal of Geographical Information Science, Vol. 25, No. 1, 2011, pp. 51-64. 